\title{
The Challenge of Moral Decadence Perspectives on the Study of Al-Arba'in An-Nawawiyah Hadith
}

\author{
* Ahmad Za'imul Umam ${ }^{1}$, Abdul Muhid ${ }^{2}$ \\ ${ }^{1,2}$ Universitas Islam Negeri (UIN) Sunan Ampel, Jl. Ahmad Yani No.117 Surabaya, \\ East Java, Indonesia \\ *elumam23@gmail.com
}

\begin{abstract}
The phenomenon of moral decadence is a topic that never dims. Like an endless sea, problem after problems related to the moral decline of the nation's children continues to roll over time. Religious education has an important role in overcoming moral problems that never end. Hadith as the basis of the second Islamic law certainly has a very basic position in Islamic education. Among the thousands of hadiths in the Islamic books, there are 40 hadith selected by Imam Nawawi, then collected in a book called al-arbain al-nawawiyah. The book al-arbain al-nawawiyah received an extraordinary reception from all corners of the world, even the book became a mandatory lesson in Indonesian Islamic Boarding Schools in general. The development of the times brought its challenges in moral matters, especially for the millennial generation. Presumably, the actualization and contextualization of moral values in the book needs to be done. So that found moral values that are relevant to the times. In the end, moral values can easily be understood and practiced. And after researching the study of literature from various related references, the authors find that there are moral values that are relevant for overcoming the problem of decadence that is increasingly afflicting. So it is proper for moral studies to be found in the book of al-arbain al-nawawiyah to be studied not only in pesantren but also in other formal and informal institutions.
\end{abstract}

Fenomena dekadensi moral adalah topik yang tak pernah redup. Bagaikan laut yang tak bertepi masalah demi masalah terkait kemerosotan moral anak bangsa terus bergulir seiring berjalannya waktu. Pendidikan agama mempunyai peran yang penting dalam mengatasi permasalahan moral yang tak kunjung usai. Hadits sebagai dasar hukum islam yang kedua sudah barang tentu mempunyai posisi yang sangat mendasar dalam pendidikan islam. Diantara ribuan hadits dalam kitab-kitab islam, terdapat 40 hadits yang dipilih oleh imam Nawawi,kemudian dikumpulkan dalam satu kitab yang disebut dengan kitab al-arbain al-nawawiyah. Kitab al-arbain alnawawiyah mendapat sambutan yang luarbiasa dari seluruh penjuru dunia, bahkan kitab tersebut menjadi pelajaran wajib dipesantren-pesantren indonesia pada umumnya. Perkembangan zaman membawa tantangan tersendiri dalam masalah moral, terutama untuk generasi milenial. Kiranya reaktualisasi dan kontektualisasi nilai moral dalam kitab tersebut perlu dilakukan. Sehingga ditemukan nilai nilai moral yang relevan dengan perkembangan zaman. Yang pada akhirnya nilai-nilai moral itu dengan 
mudah dapat dipahami dan diamalkan. Dan setelah dilakukan penelitian melalui study pustaka dari berbagai rujukan yang terkait, penulis menemukan bahwa terdapat nilai nilai moral yang relevan untuk menanggulangi masalah dekadensi yang kian melanda. Maka sudah selayaknya kajian kajian moral yang terdapat dalam kitab al-arbain alnawawiyah untuk dipelajari tidak hanya dipesantren tetapi juga di lembaga formal dan informal lainnya.

\section{Keywords: Moral, Hadits 'Arbain and Imam Nawawi.}

Received: March 2, 2020; Revised: June 5, 2020; Accepted: June 7, 2020

\section{INTRODUCTION}

Talking about moral decadence is a discussion that never goes out of style. Like an endless sea, even a problem after problem new problems keeps coming in as time goes by. Recently viral news about a case of bullying carried out by several young men against a 12-year-old child seller of fried food (Wahyu Ardianti Woro Seto, 2020). Though news recently spread about the murder of a toddler committed by a 15-yearold child, and it was by Deputy Chairman of the Indonesian Ulema Council (MUI) Advisory Council Didin Hafidhudin was seen as a warning of the lack of religious education ("Remaja Bunuh Balita, Didin: Warning Pendidikan Agama," 2020). and after the case was revealed, it turned out that there were other cases of crime that had befallen the perpetrators, the perpetrators turned out to be victims of sexual abuse committed by three of his closest people (Velarosdela, 2020). previously there was also news of a case of torturing a cat to death, (Rosidin, 2019) whereas in a hadith the prophet is told that there was a woman who went to hell because she killed a cat (Hanbal, 2001).

A study with the theme of the Relationship Between Religiosity and Morality of Youth concluded that the existence of religiosity dramatically affects one's morality, a less religious person is more likely to act immorally (Remaja, Madrasah, Ma, \& Reza, 2013). Of course, this conclusion does not only apply to adolescents but applies in general to both young and old, as the opinion of majority scholars that "Ibrah applies in general, not specifically to the perpetrators or related causes" (Al-Maqdisi, 2002).

Besides, research conducted by Idrus Ruslan, about development carried out in Indonesia in the form of physical or non-physical (mental). Concludes, that the religious spirit embedded in Pancasila is following the spirit that exists in the teachings of Islam both in the Koran and Hadith (Ruslan, 2013).

Talking about Islamic law, it is certainly inseparable from the discussion of the hadith. Because the hadith is the second basis of Islamic law after al Qu'ran (Al-Maliki, n.d.). While the definition of hadith is all matters relating to the Prophet, or companions, or tabiin, whether in the form of words, deeds, approval, or nature (Al-Maliki, n.d.). And among the books of hadith, the most recognized its validity is the book of Sahih Bukhari (Al-Maliki, n.d.). But even so does not deny the books of the other hadith, even according to the agreement of scholars of hadith experts, that the Da'eef hadith can still be used as the basis of the virtues of a charity with 3 conditions; not excessively dha'if, regardless of the path of history of people suspected of lying, is still based on a global proposition (Al-Iid, 2003). 
So great was the attention of scholars about the science of hadith, that we witness that in addition to the large books containing thousands of hadith, there are also books that contain only 40 hadiths. Imam Nawawi is a scholar of the many scholars who wrote the book containing 40 hadiths, in the future referred to like the book "al-Arbain alNawawiyah". Limiting the number of hadiths to 40 is certainly not without cause, but there is an encouragement to disseminate the hadith and to be easily learned and easily memorized (Al-Dhimyati, 1998). Even though there is also a hadith that contains the virtues and suggestions for memorizing 40 prophetic hadiths, but the hadith is stated as a hadith dha'if (Al-Haitami, 2008). On the other hand, to instill the value of moral content in the hadith more broadly and deeply, the actualization and contextualization of the hadith are very important along with the times (Suryadilaga, 2017).

Although many researchers discuss the book of al-arbain al-nawawiyah, it is still rare to review the conflict with morals, plus many writings that are too long and deep, it requires a brief, concise and straightforward review. Following the above reasons, the author is encouraged to research moral values in the book al-Arbain al-Nawawiyah, and their relevance in answering the discussion of moral decadence that continues to roll in this beloved country, as well as being strengthened and added to the expected literature (Ikhwan, 2017).

\section{LITERATURE REVIEW}

Moral in terms of its native language, the word mores, means "the rules of decency" if translated into English comes to the moral word meaning standards of behavior or principles of right and wrong (Hornby \& Cowie, 1995). In Greek, the word ethos has almost the same meaning, and henceforth is known as ethics (Puspoprodjo, 1999). Whereas in Arabic the word akhlâq has the purpose of character or customs (Sidiq, 2019). In Indonesian, several word terms have a meaning related to morals, such as morality, character, personality. If the word is referred to as a person's attribute, then what is meant is related to moral issues. But the word that is often used to represent morality is ethics (Sahmiar, 2011).

In real life, decency is often translated as instructions for behaving politely, and not obscene. So, morality is a rule of decency which includes all norms for good conduct and behavior (Gunawan Setiardja, 1990). Especially for adolescents, which is a period of a human life journey that has experienced the most change. that's why in adolescence there may be a lot of shock and uncertainty in themselves (Hanif \& Mutakin, 2019). On the other hand, excessive physical development and energy during adolescence are one of the reasons their behavior seems to be less polite, rude, and awkward (Kartono, 1995).

According to Al-Ghazali. Moral values in Islam can not be separated from the four main principles, namely (Al-Ghazali, 1986):

1. Wisdom, knowledge competence to establish the best choices in thinking, acting, and acting.

2. 'Adalah, mental abilities in conditioning and directing lust and emotions in objective truth

3. 'Iffah, an energetic attitude towards not falling into pragmatic and hedonic actions.

4. Syajâ'ah, courageous attitude in carrying out duties and obligations by using reason and morals. 
These four principles are the moral basis for controlling the conscience of the heart, and which can ultimately affect behavior.

While the method of moral internalization according to Mustafa al-thahan can be done in several ways, namely: (1) al-Qudwah (Exemplary), (2) al-Taujīh wa al-Mau'izah (Guidance and Advice), (3) al-Hiwar wa al Mas'alah (Dialogue and Questions and Answers), (4) al-Hadats (Stories / Events), (5) Ihyā 'al-Damīr (Soul Awakening / Motivation). (6) al-Targhīb (Reward) wa al-Tarhīb (Punishment) (Al-Tahhan, 2009).

According to Allen and Ryan, in dialogue an educator must apply several tricks or tricks, namely: a) Probing questions; meaning tracking questions, i.e. using follow-up questions to deepen or to further explore the answers needed from students, b) Higherorder questions; or follow-up questions, i.e. follow-up questions that are asked to students to improve learning abilities more analytically and comprehensively, c) Divergent questions; namely different questions, skills to raise different forms of questions on an issue that wants to be asked (Sukirman, 2012). According to Abdul Muhid, punishment should only be done if it is felt to be very urgent and there is no other way (Muhid, Asnawi, \& S. A. P., 2018).

\section{METHOD}

This research is library research (library research), which is research that seeks to obtain data using library sources (Ikhwan, 2013). The data that is the center of this study are collected through variable data that relies on the writings, thoughts, and opinions of figures and experts who talk about the main research theme (Sugiono, 2017). While the subject is the hadith contained in the book of al-Arbain alNawawiyah. The hadiths which are the subject of research are those related to morals in the book of al-Arbain al-Nawawiyah. The process of collecting data is done by identifying the hadith related to morals, then analyzed with a qualitative data analysis model.

\section{RESULT AND DISCUSSION}

\section{The Book of Al-Arbain Nawawiyah and Imam Nawawi}

\section{Biography of Imam Nawawi}

His full name is Yahya Ibn Syaraf Ibn Muri bin Hasan Ibn Husain Ibn Muhammad Ibn Jum'ah Ibn Hizam. (Al-Haitami, 2008)He was nicknamed Abu Zakaria because he was named Yahya. As is the custom of the Arabs to call a person named Yahya with the nickname ashes of Zechariah, because the Prophet Yahya is the son of the prophet Zachariah, in the hope that they can imitate both. While Al-Hizami is lean back to his grandfather named hizam (Farid, 2007).

An-Nawawi's nickname is because he is from the village of Nawa. He was also nicknamed Muhyiddin because he enlivened the Shafi'i madhzab with his written works. He was born in the month of Muharram in 630 or $631 \mathrm{AH}$ in the village of Nawa, a village in the Damascus Region (Al-Dhimyati, 1998). Imam Nawawi is known as a scholar of zuhud, and wara ', he fasts a lot in his daily life (Ikhwan, 2019).

$\mathrm{He}$ is a figure of a highly productive cleric, this is evidenced by the many of his works as follows (Farid, 2007): 
1) Field of Hadith: a) Al-Irsyat ila bayan Al-Asma 'Al-Mubhamat, b) Al-Adzkar, c) AlIrshad, d) Syarh Saheeh Al-Bukhari, f) Syarh Shohih Muslim, g) Al-Arbain alNawawiyah, h) At-Taqrib, i) Khulashah Al-Ahkam min Muhimmat Al-Sunan wa Qawa'id Al-Islam, j) Riyadh al-Saliheen.

2) Fiqh Field: a) Al-Idhah, b) Al-Minhaj, c) Al-Majmu 'Syarah Al-Muhadzab, d) AtTahqiq, e) Raudh Ath-Thalibin.

3) Education and Ethics: a) Bustan Al-Arifin, b) Tibyan fi Adab Hamalah Al-Qur'an.

4) Biography and Language: a) Thabaqat Al-Fuqaha', b) Tahdzib Al-Asma 'wa AlLughat, c) Tahrir At-Tanbih.

\section{Al-Arbain Al-Nawawiyah Book}

Al-arbain in language means 40, while al-nawawiyah is a response to Imam Nawawi, which means al-arbain al-nawawiyah book is a book containing 40 hadith compiled by Imam Nawawi. Even though the total number of hadiths in the book is 42 traditions. But that becomes commonplace because there is a rule "the number cannot be ascertained with a certain amount" as the opinion of Abu shama al-Maqdisi (AlThawil, 1985).

Many scholars are so interested in the book of al-Arbain al-Nawawiyah, that there appears various sharia which explains the contents of the book (Al-Dhimyati, 1998). There were even more than 40 scholars written in the form of syarh and hasyiyah alArbain al-Nawawiyah (Al-Haitami, 2008). This book is one of the basic curricula on Islamic boarding schools in Indonesia in general. (Stiawan \& Tohirin, 2015) One of the highlights of the book al-Arbain al-Nawawiyah is that it turns out that there is also a value in the value of Islamic education, namely: the value of worship, the amount of Ihsan and the value of da'wah (Tantowi, 2018). Another unique thing in the book of alArbain al-Nawawiyah also there is the formation and meaning of command words that have intrinsic and majazi meaning, thus increasing the treasury of Arabic literature when studying it (Anwar, 2016).

Al-Arbain al-Nawawiyah Book is a book that is very phenomenal and popular in the Islamic community, especially for the Indonesian Islamic society. Even the book has been translated into various languages, including Indonesian. For the people of Indonesia, it is also very easy to get the book, because both the book and its translation are printed not just one printing press. Then the possibility of people who do not understand the book al-Arbain al-Nawawiyah is due to a lack of motivation and motivation to read and study it (Matlekat, 2019).

Along with the development of increasingly sophisticated technology, the book alArbain al-Nawawiyah also has made many digital versions with an attractive interface, so that every smartphone user can access easily (Muhammad Afif Effindi \& Nur Alifah, 2015). Among them are E-Hadits based on Java Eclipse (Rakhmah, 2016). Their fact there is also the design of the book Syarh al-Arbain al-Nawawiyah with the Knuth Morris Pratt (KMP) string matching method. The use of the Knuth Morris Pratt method is intended to facilitate the search for content and topics to be searched. So it's easier to learn it. The search model used in KMP uses pattern matching between keyword patterns and patterns in the text. But unfortunately, the application was formed using the Java programming language based on desktop and can only be operated on computers that use the Windows OS (Wahyono, 2017). 
The efforts made by Syamsul Rizal and Anna Mukhayaroh also should be appreciated, related to the making of an interactive application that includes the book al-Arbain alNawawiyah. The app displays an interactive audiovisual animation stimulating and motivating students to memorize the hadith 'Arbain (Rizal \& Mukhayaroh, 2018).

\section{Moral Value in the Book of Al-Arbain Nawawiyah}

Among the popular hadiths that form the basis for moral cultivation in the book of alarbain al-nawawiyah is the second order of hadith about the meaning of Ihsan; "Gabriel asked: explain to me about the meaning of Ihsan?, The Prophet replied: Ihsan is that you should worship Allah as if you would see it, even though you cannot see it, indeed he sees you" al-Ghazali explains that ihsân includes three elements of inner awareness namely (Al-Ghazali, 1986):

First, a sensitive theological feeling and closeness to God. It was divided into 2 levels; Musyahadah and Muraqabah. Musyahadah is a position where a servant kneels before God and he can witness with his inner eyes that God is real. While muraqabah is the position of a servant kneeling before God but his inner eye cannot see his whereabouts, but he believes in his presence and supervision at all times.

Second, a sense of caring about social conditions, which starts from the scope of the family to the relationship with all the creatures of God that is wider. Allah SWT said:

"Worship Allah and do not associate Him with anything. And do good to two parents, close relatives, orphans, poor people, close neighbors and distant neighbors, distant friends, peers, ibn sabil, and your servants. Surely Allah does not like people who are arrogant and proud of themselves "(Surah An-Nisa ': 36).

Third, a strong mentality, so that he will be patient when he gets a disaster, and be brave in living a hard life. Such can be observed from the following words of Allah SWT:

"Indeed, we give back to those who do good". (Surah As-Saffat: 80)

Hadith sequence number 24 in the book al-Arbain al-Nawawiyah about the prohibition of wrongdoing is also a strong foundation related to the issue of moral urgency in Islam. As the following text:

"O my servant, in truth, I have forbidden tyranny over myself and I have made it forbidden to you. Therefore, do not do wrong to one another "(Muslim HR)

All things that are contrary to the norm that should be is tyranny (Al-Thabari, 2001). So the practice of behavior that deviates from the way that should be strictly prohibited in Islam. In other words, all human actions and behavior must be following applicable morals and norms. As Ahmad Syauqi's statement is very popular "truly the nation will remain victorious as long as they still have morals, if their morals are gone, then the nation will disappear" (Al-Mahdi, 2009).

The urgency of this character is also the main mission of the Prophet Muhammad as he said:

"I was sent (Allah) to perfect good character" (HR Ahmad)(Hanbal, 2001)

To fully understand the content of moral values contained in the book of Al-Arbain AlNawawiyah, the authors conclude the following points:

Table 1. 
Values in Al-arba'in an-nawawiyah's Hadith

\begin{tabular}{|c|c|c|c|}
\hline No & Theme & Hadith Text & Mora \\
\hline 1 & $\begin{array}{l}\text { the importance to pay } \\
\text { attention to intentions } \\
\text { and motivations in all } \\
\text { deeds }\end{array}$ & 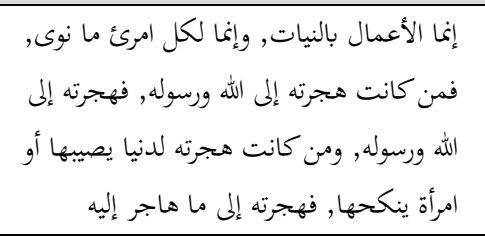 & $\begin{array}{l}\text { Always oriented to } \\
\text { kindness and only hope } \\
\text { in Allah }\end{array}$ \\
\hline 2 & $\begin{array}{l}\text { Explanation of the } \\
\text { meaning and essence of } \\
\text { Islam, faith and ihsan. } \\
\text { Then close with an } \\
\text { explanation of the } \\
\text { arrival of the Day of } \\
\text { Judgment, as well as } \\
\text { teaching methods of } \\
\text { dialogue in conveying } \\
\text { the truth. }\end{array}$ & 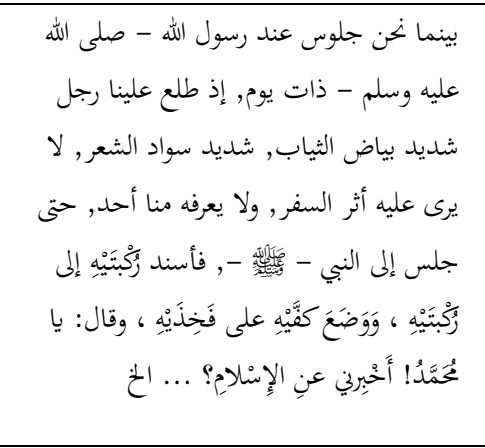 & $\begin{array}{l}\text { Being a human being } \\
\text { who is religious, has } \\
\text { theological sensitivity, } \\
\text { and has a high social } \\
\text { life. Besides having the } \\
\text { spirit of learning to seek } \\
\text { and accept the truth. }\end{array}$ \\
\hline 3 & $\begin{array}{l}\text { Explanation of the } \\
\text { meaning and essence of } \\
\text { Islam. }\end{array}$ & 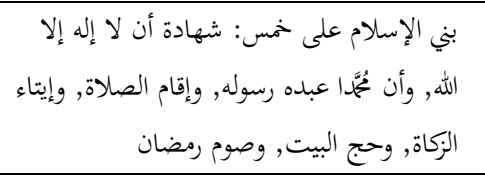 & $\begin{array}{l}\text { Become a religious } \\
\text { man. }\end{array}$ \\
\hline 4 & $\begin{array}{l}\text { The process of human } \\
\text { creation originating } \\
\text { from semen, to the } \\
\text { destiny of life that will } \\
\text { be accepted in the world } \\
\text { and the determination in } \\
\text { the hereafter. }\end{array}$ & 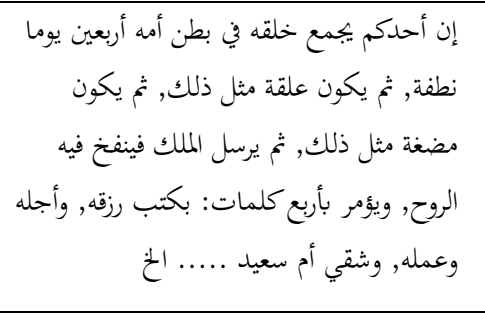 & $\begin{array}{l}\text { Believe in the power of } \\
\text { God in addition to the } \\
\text { work done by humans. } \\
\text { So that it doesn't } \\
\text { become arrogant and } \\
\text { doesn't give up with } \\
\text { limited abilities. }\end{array}$ \\
\hline 5 & $\begin{array}{l}\text { Provisions on religious } \\
\text { boundaries }\end{array}$ & مَنْ أَحْدَثَ في أَمْرِنا هَذا مَا لَيْنَ مِنْهُ هَهَ ردّ & $\begin{array}{l}\text { Paying attention to the } \\
\text { prevailing norms and } \\
\text { trying to always obey } \\
\text { them. }\end{array}$ \\
\hline 6 & $\begin{array}{l}\text { The limits of halal and } \\
\text { haram, and the thing } \\
\text { between them is } \\
\text { doubtful. And the heart } \\
\text { is the central organ in } \\
\text { the human body that } \\
\text { determines good and } \\
\text { evil. }\end{array}$ & 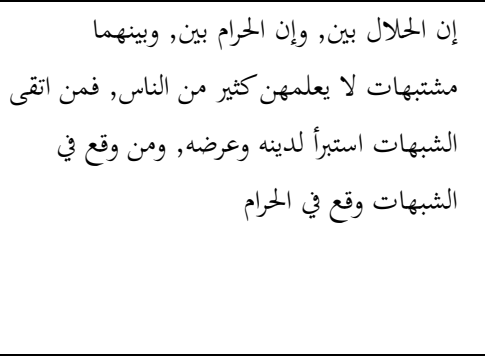 & $\begin{array}{l}\text { Keep yourself from } \\
\text { things that are unclean } \\
\text { and not good, and } \\
\text { always be careful of } \\
\text { things that are not clear. } \\
\text { Besides controlling the } \\
\text { heart to always be } \\
\text { directed in goodness. }\end{array}$ \\
\hline 7 & $\begin{array}{l}\text { Religion as good advice } \\
\text { in human life }\end{array}$ & 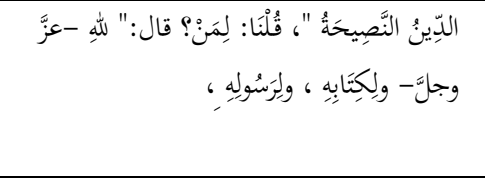 & $\begin{array}{l}\text { Always try to remind } \\
\text { ourselves of the rights } \\
\text { of God and the rights of } \\
\text { fellow humans }\end{array}$ \\
\hline 8 & $\begin{array}{l}\text { The principles of } \\
\text { guarantee in Islam and } \\
\text { the obligations of } \\
\text { adherents }\end{array}$ & 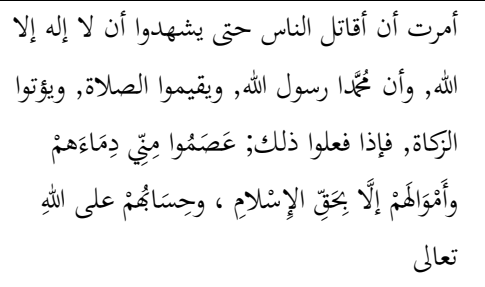 & $\begin{array}{l}\text { Carry out religious } \\
\text { obligations as well as } \\
\text { possible }\end{array}$ \\
\hline 9 & $\begin{array}{l}\text { Limits to run orders and } \\
\text { stay away from }\end{array}$ & ما غيتكم عنه فاجتنبوه, وما أمرتكم به فأتوا منه & $\begin{array}{l}\text { Obey the rules and not } \\
\text { much fighting }\end{array}$ \\
\hline
\end{tabular}


51 Al-Hayat: Journal of Islamic Education (AJIE)

e-ISSN: 2599-3046 (online) | Volume 4, Issue 1 | January - June 2020

p-ISSN: $2657-1781$ (print)

\begin{tabular}{|c|c|c|c|}
\hline & restrictions in Islam & ما مسائلهم, واختمتر فإنما أهلك الذين من قبلكم كثرة & \\
\hline 10 & $\begin{array}{l}\text { The importance of halal } \\
\text { business and prosperity } \\
\text { and its influence on } \\
\text { prayer. } \\
\text { Business and prosperity } \\
\text { is not measured by } \\
\text { appearance and } \\
\text { appearance. }\end{array}$ & 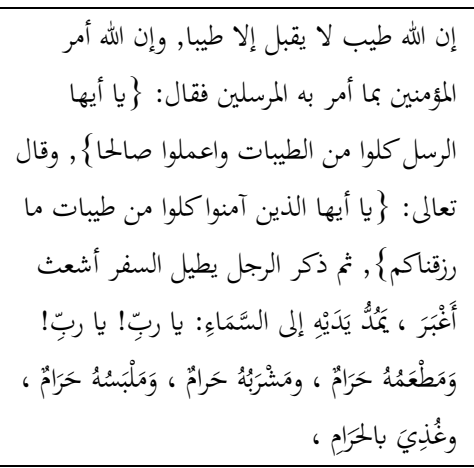 & $\begin{array}{l}\text { Looking for good in a } \\
\text { good way and Trying } \\
\text { with the right effort. }\end{array}$ \\
\hline 11 & Faith conquers doubt & دَعْ مَا يَرِيُكَكَ إلى مَا لا يَرِيُّك & $\begin{array}{l}\text { Be optimistic, and do } \\
\text { not hesitate hesitate in } \\
\text { stepping }\end{array}$ \\
\hline 12 & Leaving vain things & 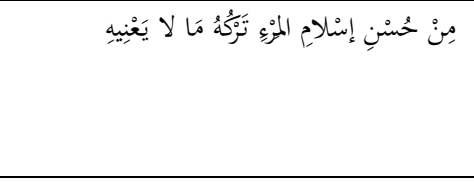 & $\begin{array}{l}\text { Focus on the things that } \\
\text { are important, } \\
\text { regardless of the things } \\
\text { that are in vain }\end{array}$ \\
\hline 13 & $\begin{array}{l}\text { A person's faith is } \\
\text { measured by his love for } \\
\text { his brother }\end{array}$ & 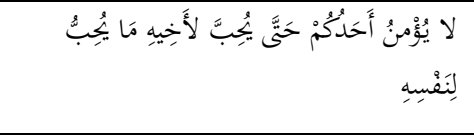 & Loving others \\
\hline 14 & $\begin{array}{l}\text { Things that deprive } \\
\text { Muslims of honor }\end{array}$ & 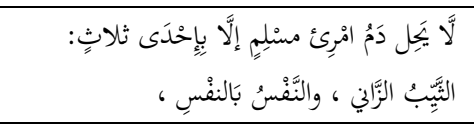 & Maintain self-respect \\
\hline 15 & $\begin{array}{l}\text { Good words, respect for } \\
\text { neighbors and guests as } \\
\text { a sign of faith }\end{array}$ & 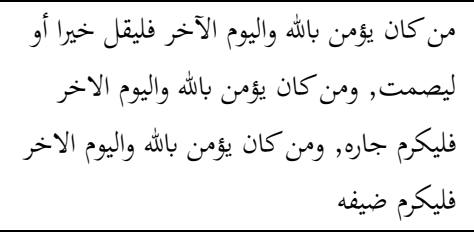 & $\begin{array}{l}\text { Good words, or silence } \\
\text { can be a choice if you } \\
\text { can not say good. } \\
\text { respecting neighbors, } \\
\text { and glorifying guests }\end{array}$ \\
\hline 16 & $\begin{array}{l}\text { Restrain emotions and } \\
\text { anger }\end{array}$ & 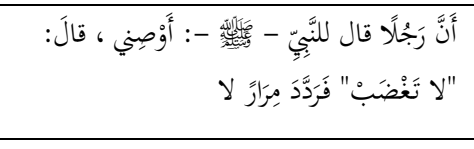 & $\begin{array}{lr}\text { Refrain } & \text { from } \\
\text { unnecessary } & \text { emotions } \\
\text { and anger } & \\
\end{array}$ \\
\hline 17 & Be polite to all beings & 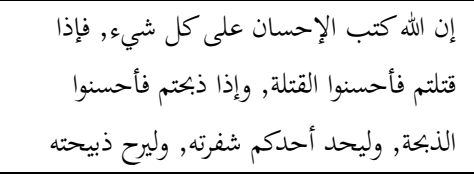 & $\begin{array}{l}\text { Be polite to all beings, } \\
\text { even to animals }\end{array}$ \\
\hline 18 & $\begin{array}{l}\text { Obey Allah, cover the } \\
\text { bad with goodness, and } \\
\text { behave politely }\end{array}$ & 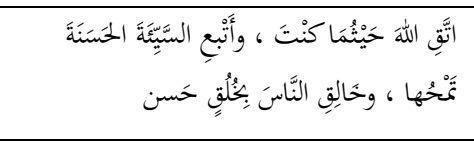 & $\begin{array}{l}\text { Behave politely, and } \\
\text { always correct mistakes. }\end{array}$ \\
\hline 19 & $\begin{array}{l}\text { Belief in the power of } \\
\text { God in all things }\end{array}$ & 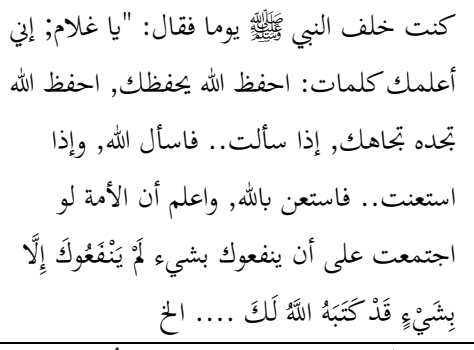 & $\begin{array}{l}\text { Feeling under God's } \\
\text { control, not giving up } \\
\text { on the situation }\end{array}$ \\
\hline 20 & Shyness is a sign of faith & 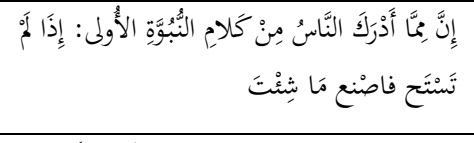 & $\begin{array}{l}\text { Feeling ashamed to do } \\
\text { wrong and deny the } \\
\text { norm }\end{array}$ \\
\hline 21 & $\begin{array}{l}\text { Attitude istiqomah one } \\
\text { of the main points of }\end{array}$ & يا رَسولَ الله! قُلْ لي في الإسْلاِح قَوْلاً لا أَسْأل & $\begin{array}{l}\text { Act istiqomah, and not } \\
\text { easily swayed }\end{array}$ \\
\hline
\end{tabular}




\begin{tabular}{|c|c|c|c|}
\hline & Islamic teachings & 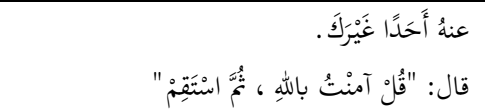 & \\
\hline 22 & $\begin{array}{l}\text { Carrying out orders and } \\
\text { avoiding prohibitions is } \\
\text { the key to entering } \\
\text { heaven }\end{array}$ & 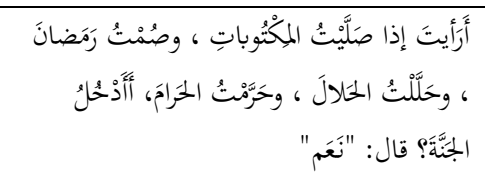 & $\begin{array}{l}\text { Obey the rules and don't } \\
\text { break the ban }\end{array}$ \\
\hline 23 & Kind of kindness path & 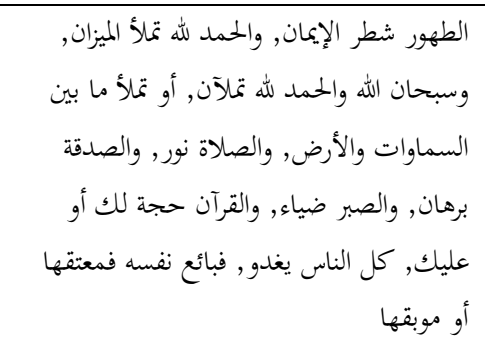 & $\begin{array}{l}\text { There is no reason not } \\
\text { to do good }\end{array}$ \\
\hline 24 & $\begin{array}{l}\text { Prohibition of doing } \\
\text { wrong, and innumerable } \\
\text { gifts of god }\end{array}$ & 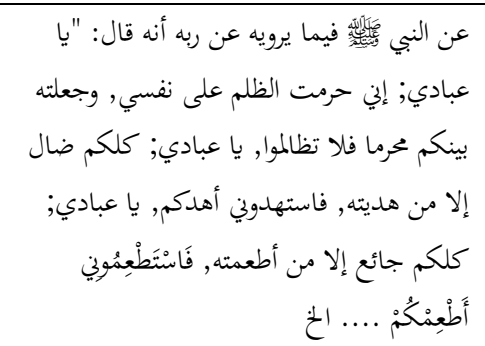 & $\begin{array}{l}\text { Do not persecute, } \\
\text { realize that all that is } \\
\text { owned cannot be } \\
\text { separated from the grace } \\
\text { and mercy of God }\end{array}$ \\
\hline 25 & $\begin{array}{l}\text { The virtue of dhikr, and } \\
\text { competing in goodness }\end{array}$ & 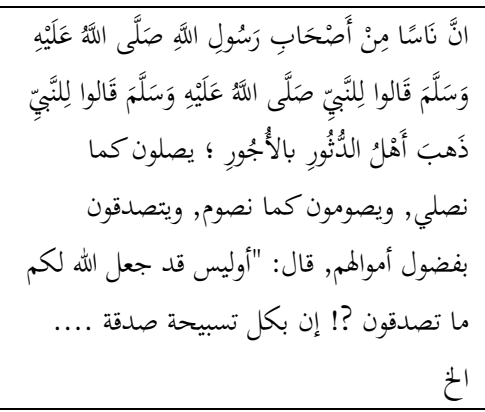 & $\begin{array}{l}\text { Race in kindness, } \\
\text { always remember the } \\
\text { nature of yourself and } \\
\text { the presence of God. }\end{array}$ \\
\hline 26 & $\begin{array}{l}\text { There are many things } \\
\text { to be grateful for with } \\
\text { shodaqoh, there are also } \\
\text { many ways to do good } \\
\text { and shodaqoh }\end{array}$ & 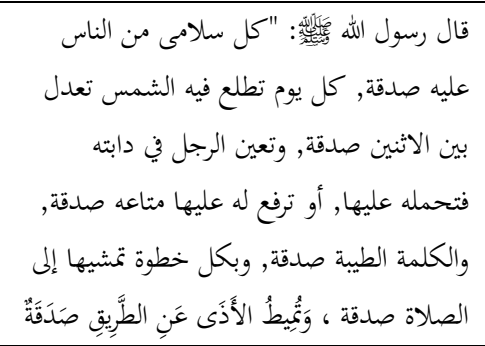 & $\begin{array}{l}\text { Grateful for everything } \\
\text { that is owned, gives a } \\
\text { lot of kindness, and } \\
\text { there is no reason to do } \\
\text { good. }\end{array}$ \\
\hline 27 & $\begin{array}{l}\text { Definition of virtue and } \\
\text { sin }\end{array}$ & 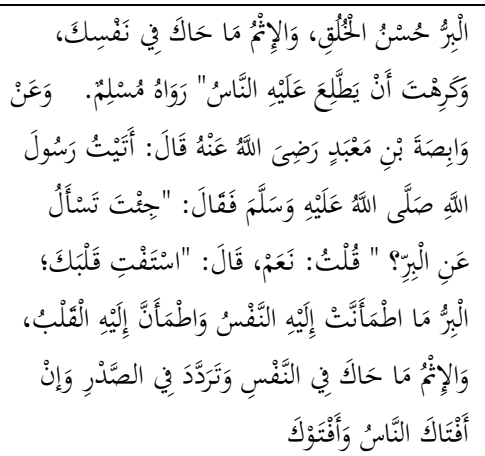 & $\begin{array}{l}\text { Always consider things } \\
\text { before acting, believing } \\
\text { what is wrong is still } \\
\text { wrong even if it is } \\
\text { supported by many } \\
\text { people }\end{array}$ \\
\hline 28 & $\begin{array}{l}\text { Obedience to the leader, } \\
\text { and uphold the prophet's } \\
\text { sunnah }\end{array}$ & 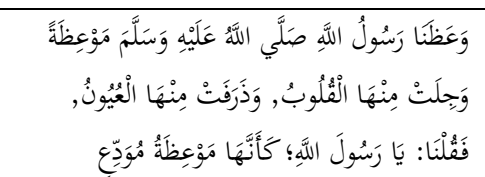 & $\begin{array}{l}\text { Become an obedient } \\
\text { citizen, and hold } \\
\text { principles firmly }\end{array}$ \\
\hline
\end{tabular}




\begin{tabular}{|c|c|c|c|}
\hline & & 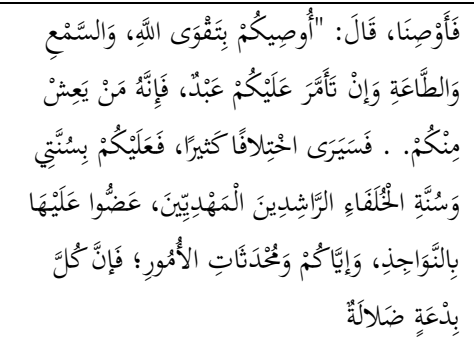 & \\
\hline 29 & The road to safety & 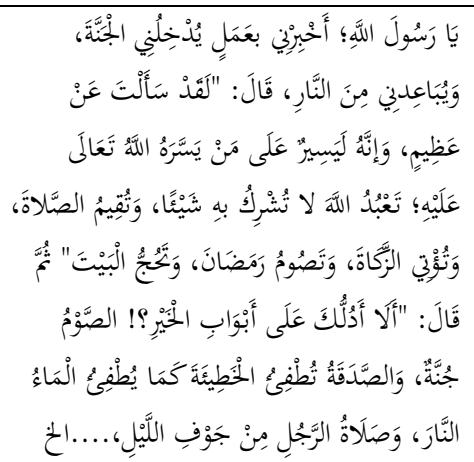 & $\begin{array}{l}\text { Trying to stay away } \\
\text { from mistakes, find } \\
\text { ways of goodness, and } \\
\text { keep verbal }\end{array}$ \\
\hline 30 & $\begin{array}{l}\text { Comply with the limits } \\
\text { of Shari'a, and do not } \\
\text { ask unnecessary things }\end{array}$ & 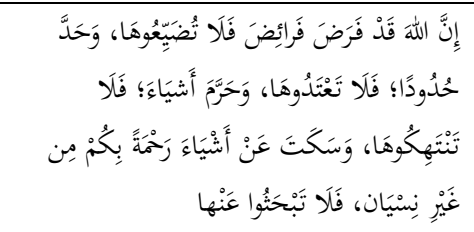 & $\begin{array}{l}\text { Obey the rules, and } \\
\text { don't ask many } \\
\text { questions that aren't } \\
\text { needed }\end{array}$ \\
\hline 31 & $\begin{array}{l}\text { The virtue of zuhud in } \\
\text { world affairs }\end{array}$ & 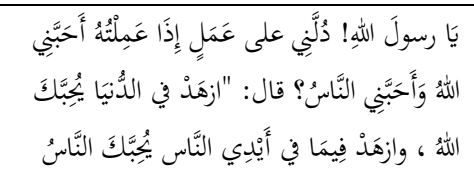 & $\begin{array}{l}\text { Not greedy and greedy, } \\
\text { and not crazy in } \\
\text { popularity }\end{array}$ \\
\hline 32 & $\begin{array}{l}\text { Do not spread the } \\
\text { danger, and endanger } \\
\text { others }\end{array}$ & لَا ضَرَرَ وَلَا ضِرَارَ & $\begin{array}{l}\text { Does not endanger } \\
\text { others, and is not } \\
\text { provoked to spread } \\
\text { danger to each other }\end{array}$ \\
\hline 33 & $\begin{array}{l}\text { The principle of legal } \\
\text { decisions in Islam }\end{array}$ & 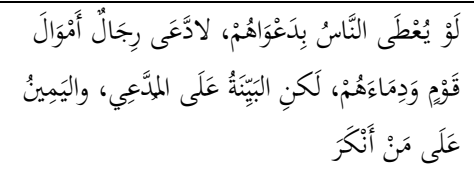 & $\begin{array}{l}\text { Express confession with } \\
\text { clear evidence }\end{array}$ \\
\hline 34 & $\begin{array}{l}\text { The level of prevention } \\
\text { of violations }\end{array}$ & 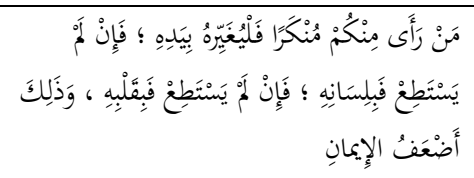 & $\begin{array}{l}\text { Always try to prevent } \\
\text { bad things and be as bad } \\
\text { as possible }\end{array}$ \\
\hline 35 & $\begin{array}{l}\text { Brotherhood between } \\
\text { Muslims and their rights }\end{array}$ & 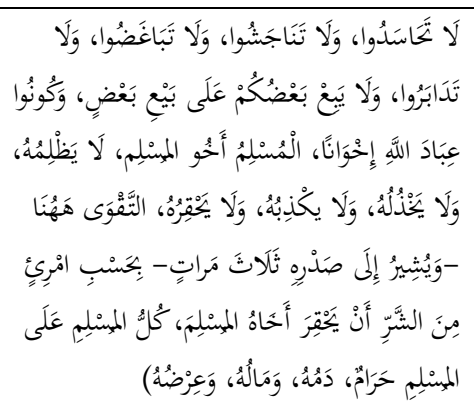 & $\begin{array}{l}\text { Creating a sense of } \\
\text { brotherhood, not hostile } \\
\text { to each other and find } \\
\text { fault with each other }\end{array}$ \\
\hline 36 & $\begin{array}{l}\text { Facilitating the } \\
\text { difficulties of others, } \\
\text { and the virtue of seeking } \\
\text { knowledge }\end{array}$ & 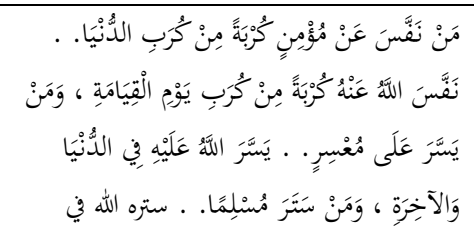 & $\begin{array}{l}\text { Likes to help and help } \\
\text { others, as well as study } \\
\text { hard to study }\end{array}$ \\
\hline
\end{tabular}




\begin{tabular}{|c|c|c|c|}
\hline & & 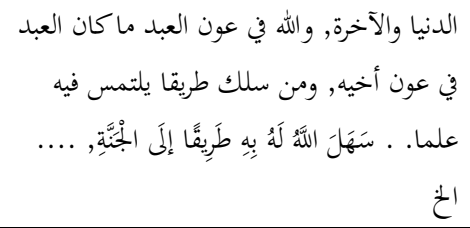 & \\
\hline 37 & $\begin{array}{l}\text { God's mercy for his } \\
\text { servant }\end{array}$ & 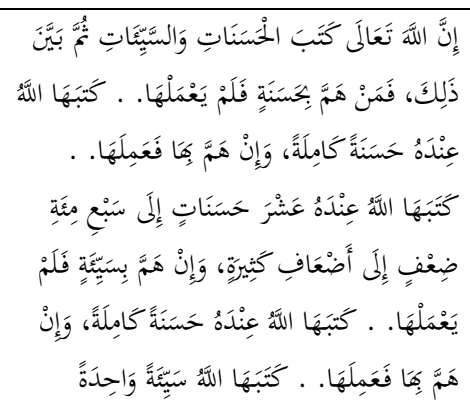 & $\begin{array}{l}\text { Realizing the love and } \\
\text { mercy of God, so as not } \\
\text { to waste goodness, and } \\
\text { not to underestimate } \\
\text { badness }\end{array}$ \\
\hline 38 & $\begin{array}{l}\text { Allah's love for the } \\
\text { saints (people close to } \\
\text { him), and the road to } \\
\text { him }\end{array}$ & 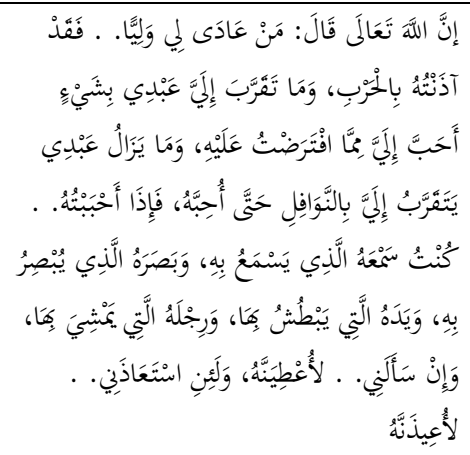 & $\begin{array}{l}\text { Trying to be close to } \\
\text { God by following the } \\
\text { instructions }\end{array}$ \\
\hline 39 & $\begin{array}{l}\text { This is understandable } \\
\text { in Islam }\end{array}$ & 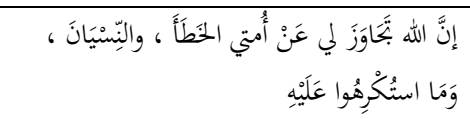 & $\begin{array}{l}\text { Understand others' } \\
\text { unintentional mistakes }\end{array}$ \\
\hline 40 & $\begin{array}{l}\text { Appreciate time and } \\
\text { remaining life }\end{array}$ & 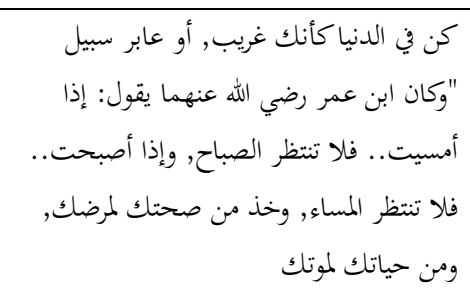 & $\begin{array}{l}\text { Discipline and on time, } \\
\text { and not delay a job }\end{array}$ \\
\hline 41 & $\begin{array}{l}\text { Following the Shari'a of } \\
\text { the Prophet }\end{array}$ & 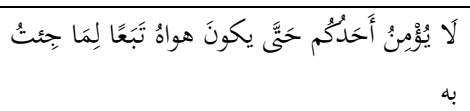 & $\begin{array}{l}\text { Obey the rules, and } \\
\text { don't act arbitrarily }\end{array}$ \\
\hline 42 & $\begin{array}{l}\text { The extent of } \\
\text { forgiveness Allah }\end{array}$ & 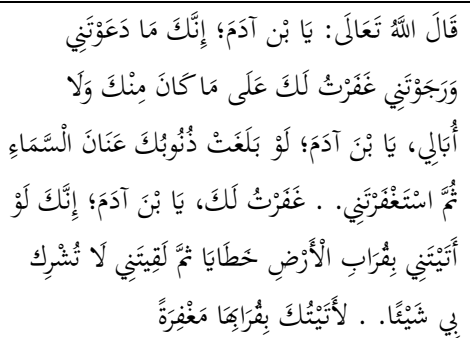 & $\begin{array}{l}\text { Do not break from the } \\
\text { grace and mercy of } \\
\text { God, and try to ask } \\
\text { forgiveness }\end{array}$ \\
\hline
\end{tabular}

The points above certainly do not represent the whole meaning and value of the hadith itself, maybe even there are still many meanings and values that have not been revealed. Nevertheless, from the table above, at least it can be understood that in every hadith from the book al-arbain al-nawawiyah there are relevant moral values. If these values are taught and applied in formal or informal institutions, or even at the level of society in general, it certainly can be part of an effective solution to answer various problems of moral decadence that are increasingly endemic. 


\section{CONCLUSION}

Religiosity is very influential on a person's good effects, so among the efforts to overcome moral decadence is a religious approach. One such religious approach is the approach with the hadith of the prophet Muhammad, especially the hadith contained in the book al-arbain al-nawawiyah. al-arbain al-nawawiyah book is a monumental work of a world-renowned scholar, Imam Nawawi. In addition to being known as a zuhud scholar and fasting expert, he is also a prolific scholar with his writings. So do not be surprised if the book al-arbain al-nawawiyah into a famous book in the world, even many attention and re-translated by dozens of scholars after his death.

Kharisma Kitab al-arbain al-nawawiyah also sticks out in Indonesia, it is known that the book becomes a basic curriculum that must be studied in Indonesian Islamic boarding school in general. efforts to study continue today in the millennial era. So efforts to spread the understanding of the book are increasingly massive, including through Android applications and Windows software. Of course, in modern times such as the current understanding and meaning of the hadith needs to be actualized so that it can give a more striking picture, especially for millennials.

Among the efforts to reactivate the hadith is to study al-arbain al-nawawiyah in terms of psychology, especially morals. Researchers found moral values which were then poured into short, concise, and straightforward language. If these values are taught and applied in formal or informal institutions, or even at the level of society in general, it certainly can be part of an effective solution to answer various problems of moral decadence that are increasingly endemic.

\section{REFERENCES}

[1] Al-Dhimyati, M. I. A. (1998). Jawahir al-Lu'luiyah Fi Syarh al-Arba'in alNawawiyah (01 ed.). Beirut: al-Yamamah.

[2] Al-Ghazali, al-I. A. H. M. bin M. (1986). Ihyâ 'Ulûmuddîn. Kairo: Dâr alKutûb al-'Arabiyyah.

[3] Al-Haitami, I. H. (2008). al-Fathul al-Mubin Bi Syarh al-Arbain. Jedah: Dar alMinhaj.

[4] Al-Iid, I. D. (2003). Syarh al-Arbain al-Nawawiyah Fi al-Ahadits al-Shohihah alNabawiyah. Beirut: Muassasah al-Rayyan.

[5] Al-Mahdi, H. I. M. (2009). Shoid al-Afkar Fi al-Adab Wa al-Akhlak Wa al-Hikam Wa al-Amtsal. Yaman: Dar al-Kitab.

[6] Al-Maliki, S. M. I. 'alwi. (n.d.). al-Manhal al-Latif Fi Ushul al-Hadits al-Syarif. Surabaya: Haiah as-Shofwah al-Malikiyah.

[7] Al-Maqdisi, I. Q. (2002). Raudhah al-Nadzhir Wa Jannah al-Manadzir. Beirut: Muassasah al-Rayyan.

[8] Al-Tahhan, M. M. (2009). al-Tarbiyah wa Dauruhā fi Tasykīl al-Sulūk. Kuwait: Dār alWafā.

[9] Al-Thabari, I. J. (2001). Tafisr al-Thabari. Shan'a: Dar Hajar.

[10] Al-Thawil, al-S. R. (1985). Madkhol Fi 'ulum al-Qira'at. Saudi Arabia: al- 
Maktabah al-Faishaliyah.

[11] Anwar, C. (2016). Gaya Bahasa Perintah Dalam Hadits Arba'in Riwayat Imam An-Nawawi Serta Implikasinya Terhadap Pembelajaran Ilmu Balagah. Universitas Negeri Jakarta.

[12] Farid, S. A. (2007). Min A'lam As Salaf, Penerjemah Masturi Ilham dan Asmu'i Taman Judul 60 Biografi Ulama Salaf. Jakarta: Pustaka Al Kausar.

[13] Gunawan Setiardja, A. (1990). Dialektika Hukum dan Moral dalam Pembangunan Masyarakat Indonesia. Kanisius, Yogyakarta.

[14] Hanbal, A. I. M. I. (2001). Musnad al-Imam Ahmad Ibn Hanbal. Beirut: Muassasah al-Risalah.

[15] Hanif, M. I., \& Mutakin, Z. (2019). Community Empowerment Model Based on Islamic Education Institutions. AL-HAYAT: Journal of Islamic Education, 3(1), 82-89. https://doi.org/10.35723/ajie.v3i1.47

[16] Hornby, A. S., \& Cowie, A. P. (1995). Oxford advanced learner's dictionary (Vol. 1430). Oxford university press Oxford.

[17] Ikhwan, A. (2013). Model Organisasi Ideal Bagi Perguruan Tinggi Islam di Indonesia. Ta'allum: Jurnal Pendidikan Islam, 1(1), 29-36. Retrieved from http://ejournal.iain-tulungagung.ac.id/index.php/taalum/article/view/537

[18] Ikhwan, A. (2017). Metode Simulasi Pembelajaran dalam Perspektif Islam. Istawa: Jurnal Pendidikan Islam, 2(2), 1-34. https://doi.org/10.24269/ijpi.v2i2.623

[19] Ikhwan, A. (2019). Public Relations in an Islamic Perspective ; Implementation Study at Madrasah. At-Turats: Jurnal Pemikiran Pendidikan Islam, 13(2), 105117. https://doi.org/https://doi.org/10.24260/at-turats.v13i2.996

[20] Kartono, K. (1995). Psikologi Anak: Psikologi Perkembangan, Cet. V,(Bandung: Mandar Maju.

[21] Matlekat. (2019). Kedudukan Hadits-Hadits Dakwah Dalam Kitab Hadits Arba'in An-Nawawi. Universitas Muhammadiyah Palembang.

[22] Muhammad Afif Effindi, \& Nur Alifah. (2015). Digitalisasi Arbain Nawawi Pada Android. ENERGY: Jurnal Ilmiah Ilmu-Ilmu Teknik, 5(2), 1-5.

[23] Muhid, A., Asnawi, A., \& S. A. P., R. S. (2018). Pendidikan Moral melalui Pembelajaran Kitab Alfiyah ibn Malik di Pondok Pesantren Langitan Tuban. Jurnal Pendidikan Agama Islam (Journal of Islamic Education Studies), 6(1), 106-126. https://doi.org/10.15642/jpai.2018.6.1.106-126

[24] Puspoprodjo, W. (1999). Filsafat Moral: Kesusilaan dalam Teori dan Praktek. Bandung: Pustaka Grafika.

[25] Rakhmah, S. N. (2016). Pembuatan Aplikasi E-Hadits Pada Smartphone Berbasis Java Eclipse. Simnasiptek 2016, 1(1), 62-72.

[26] Remaja Bunuh Balita, Didin: Warning Pendidikan Agama. (2020). Republika.

[27] Remaja, P., Madrasah, D. I., Ma, A., \& Reza, I. F. (2013). Hubungan Antara Religiusitas Dengan Moralitas Pada Remaja Di Madrasah Aliyah (Ma). Hubungan Antara Religiusitas Dengan Moralitas Pada Remaja Di Madrasah Aliyah (Ma), 
10(2), 45-58. https://doi.org/10.26555/humanitas.v10i2.335

[28] Rizal, S., \& Mukhayaroh, A. (2018). Animasi Interaktif Hadits Arba'in Untuk Siswa Sekolah Dasar Islam Salman Alfarisi Bekasi. Jurnal Teknik Komputer, 4(2), 31-38.

[29] Rosidin, I. (2019). Viral Kucing Disiksa dengan Digantung di Bali, Pengunggah Foto Dipolisikan. Kompas.

[30] Ruslan, I. (2013). Membangun Harmoni Kehidupan Berbangsa dan Bernegara dengan Nilai Islam dalam Pancasila. Jurnal Tapis: Jurnal Teropong Aspirasi Politik Islam, 9(2), 1-16.

[31] Sahmiar, S. (2011). Membangun moralitas melalui pendidikan agama. AlHikmah: Jurnal Keilmuan Keislaman, 8(1), 1-17.

[32] Sidiq, U. (2019). Prophetic Leadership in the Development of Religious Culture in Modern Islamic Boarding Schools. Istawa: Jurnal Pendidikan Islam, 4(1), 8097. https://doi.org/10.24269/ijpi.v4i1.1990

[33] Stiawan, K., \& Tohirin, M. (2015). Format Pendidikan Pondok Pesantren Salafi Dalam Arus Perubahan Sosial di Kota Magelang. Cakrawala: Jurnal Studi Islam, 10(2), 194-209.

[34] Sugiono. (2017). Metode Penelitian Kuantitatif, Kualitatif, dan R\&D (25th ed.). Bandung: Alfabeta.

[35] Sukirman, D. (2012). Micro Teaching. Jakarta: Direktorat Jenderal Pendidikan Islam Kementerian Agama RI.

[36] Suryadilaga, M. A. (2017). Kontekstualisasi Hadis Dalam Kehidupan Berbangsa Dan Berbudaya. Kalam, 11(1), 215. https://doi.org/10.24042/klm.v11i1.904

[37] Tantowi, M. (2018). Nilai-Nilai Pendidikan Islam Dalam Kitab Hadits Arba'in Karangan Imam An-Nawawi. UIN Raden Intan Lampung.

[38] Velarosdela, R. N. (2020). Fakta Remaja Pembunuh Balita dalam Lemari, Jadi Korban Pelecehan Seksual hingga Hamil. Kompas.

[39] Wahyono, I. A. (2017). Perancangan Syarah Hadist Digital" Arba'in An Nawawi" Dengan Menggunakan Algoritma Pencarian Knuth-Morris-Pratt (KMP). University of Muhammadiyah Malang.

[40] Wahyu Ardianti Woro Seto. (2020). Viral Bocah Penjual Gorengan Dibully Beberapa Pemuda, Dipukul dan Didorong Sampai Tersungkur. Tribunjateng, p. 2. 